\title{
SUSAR Reporting to National Competent Authority Indicator
}

National Cancer Institute

\section{Source}

National Cancer Institute. SUSAR Reporting to National Competent Authority Indicator.

NCI Thesaurus. Code C126074.

An indication as to whether suspected unexpected serious adverse reactions will be reported to national competent authorities. 